\title{
Predictors of Functional Outcome After Treatment of Acute Ischemic Stroke
}

\author{
Emad F. Abdel-Monem, Fathy M. Afifi, and Ahmed Essmat ${ }^{*}$ \\ Department of Neurology, Al-Azhar University Faculty of Medicine, Al-Hussein University Hospital, Cairo, Egypt
}

\begin{abstract}
Background: Acute ischemic stroke (AIS) is a common condition with significant consequences. Advances in treatment modified outcome and prognosis. Aim: The present study aimed to discuss the predictors of functional outcome of AIS after the first three months. Patients and Methods: All the studied 131 patients had careful history taking, thorough clinical examination, and noncontrast brain CT scans. The initial severity of the stroke and evolution after thrombolysis was evaluated using the National Instituted of Health Stroke Scale (NIHSS). Patients were treated with low molecular weight heparin (LMWH) or rt-PA. Functional status at three months was evaluated using the modified Rankin Scale. Results: The present study included 131 patients with AIS. Favorable functional outcome was achieved in 52 patients (39.7 \%) while the remainder 79 patients had a poor outcome. Using logistic regression analysis, significant predictors of poor outcome on univariate analysis included age $\geq 60$ years (OR:3.2, $\mathrm{Cl}: 1.3-7.9, \mathrm{p}=0.014)$, presence of atheromatous plaques (OR: 16.8, Cl: 4.8-58.3, $\mathrm{p}<0.001$ ), late initiation of treatment (OR: 10.6, Cl: 3.432.1, $\mathrm{p}<0.001$ ) and persistent occlusion (OR: 7.8, $\mathrm{Cl}: 3.2-18.8, \mathrm{p}<0.001$ ). However, on multivariate analysis, variable predictive of poor outcome included age $\geq 60$ years (OR: 32.5, Cl: 5.4-196.5, $\mathrm{p}<$ 0.001), presence of atheromatous plaques (OR: 9.4, $\mathrm{Cl}$ : 1.7-51.2, $\mathrm{p}=0.01$ ), late initiation of treatment (OR: 10.0, $\mathrm{Cl}: 1.5-67.1, \mathrm{p}=0.018$ ) and persistent occlusion (OR:25.7, $\mathrm{Cl}: 6.9-95.8, \mathrm{p}<0.001)$. Conclusions: Independent predictors of poor outcome in AIS patients include age $\geq 60$ years, presence of atheromatous plaques, late initiation of treatment, and persistent occlusion.
\end{abstract}

Keywords: Acute ischemic stroke, recombinant tissue plasminogen activator, functional outcome

\section{Introduction}

Acute ischemic stroke (AIS) is related to 6.5 million annual fatalities with significant morbidities that profoundly impair patients and families quality of life and constitutes a substantial burden on the health

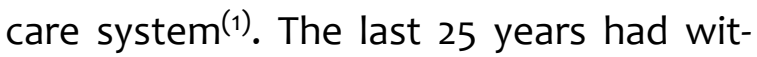
nessed considerable progress in management of AIS. Intravenous chemical thrombolysis and intra-arterial mechanical thrombectomy were approved in 1995 and 2015 respectively ${ }^{(2)}$. Intravenous thrombolysis using recombinant tissue plasminogen activator (rt-PA) remains the gold standard medical treatment of AIS. It has been evident that early recanalization of occluded blood vessels in AIS patients by rt-PA administration or endovascular revascularization is associated with improved clinical outcome and survival rates $^{(3)}$. rt-PA is particularly effective when 
administered within the first 4.5 hours after stroke onset. Delayed use, however, increases the odds of fatal intracranial hemorrhage ${ }^{(4)}$. Assessment of cerebral hemodynamics after recanalization therapy serves to understand the pathomechanics of cerebral re-perfusion and can help recognize patients at high-risk of recanalization complications(5). The present study aimed to assess the predictors of functional outcome in AIS patients at 3 months after initiation of treatment.

\section{Patients and Methods}

This retrospective study was conducted at the Stroke Unit, Al-Azhar University Hospitals, Cairo Egypt. The study protocol was approved by the local ethical committees at both centers and informed consent was obtained from the included patients or their legal guardians before initiation of treatment. Patients were included in the study if they were diagnosed with AIS. The only exclusion criterion was uncontrolled hypertension. All patients had careful history taking, thorough clinical examination and non-contrast brain $\mathrm{CT}$ scans. The initial severity of the stroke and evolution after thrombolysis was evaluated using the National Instituted of Health Stroke Scale (NIHSS). Patients were treated with low molecular weight heparin (LMWH) or rt-PA. The dose of administered rt-PA was 0.9 $\mathrm{mg} / \mathrm{kg}$ body weight with a maximum of $90 \mathrm{mg}$. According to protocol, 1/10 of total dose of rt- PA was given IV in a bolus and the remaining 9/10 were infused over 1 hour. After 24 hours of treatment, CT scan was repeated. The primary study outcome was early improvement or deterioration. Early improvement was defined according to the NINDS criteria as 4-point improvement in the NIHSS score from baseline values or complete resolution of neurological deficit. Significant clinical deterioration was defined as 2point NIHSS deterioration, new headache and vomiting developed within 24 hours post rt-PA infusion. Symptomatic intracranial hemorrhage was defined according to ECASS III as any hemorrhage with neurologic deterioration combined with an NIHSS score 4 points greater than either the baseline value or the lowest value in the first 7 days, or death ${ }^{(6)}$. The primary outcome of the present study was functional status at three months after initiation of treatment. It was evaluated using the modified Rankin Scale. Favorable outcome is defined as functional independence, with no symptoms or mild disability(7). Results obtained from this study were statistically analyzed using SPSS 25 (IBM, USA). Numerical variables were expressed as mean \pm SD or median and interquartile range while categorical data were presented as number and percent. Comparison between categorical variables was achieved using Chi-square test with $P$ value less than 0.05 indicating significant results.

\section{Results}

The present study included 131 patients with AIS. They comprised 79 males (60.3\%) and 52 females (39.7\%). Favorable functional outcome was achieved in 52 patients (39.7\%) while the remainder 79 patients had poor outcome. Comparison between patients with good and poor outcomes revealed significant association between poor outcome and age $\geq 60$ years, diabetes mellitus, deteriorated level of consciousness, presence of atheromatous plaques, late initiation of treatment, and persistent occlusion after treatment (Table 1). 


\begin{tabular}{|c|c|c|c|c|}
\hline & $\begin{array}{l}\text { All patients } \\
\qquad \mathrm{N}=131\end{array}$ & $\begin{array}{l}\text { Good out- } \\
\text { come } \\
n=52\end{array}$ & $\begin{array}{l}\text { Bad outcome } \\
\qquad n=79\end{array}$ & $P$ value \\
\hline $\begin{array}{c}\text { Age (years) n (\%) } \\
\qquad \quad<60 \\
\cdot \quad \geq 60\end{array}$ & $\begin{array}{c}24(18.3) \\
107(81.7)\end{array}$ & $\begin{array}{l}15(28.8) \\
37(71.2)\end{array}$ & $\begin{array}{c}9(11.4) \\
70(88.6)\end{array}$ & 0.012 \\
\hline $\begin{aligned} \operatorname{Sex} \mathrm{n}(\%) \\
\text { - } \\
\text { - } \quad \text { Fale } \\
\end{aligned}$ & $\begin{array}{l}79(60.3) \\
52(39.7)\end{array}$ & $\begin{array}{l}31(59.6) \\
21(40.4)\end{array}$ & $\begin{array}{c}48(60.8) \\
31(39.2)\end{array}$ & 0.9 \\
\hline $\begin{array}{l}\text { Risk factors } \mathrm{n}(\%) \\
\text { - Hypertension } \\
\text { - } \text { Dyslipidemia } \\
\text { - IHD } \\
\text { - Diabetes mellitus } \\
\text { - Smoking } \\
\text { - } \mathrm{AF}\end{array}$ & $\begin{array}{l}76(58.0) \\
60(45.8) \\
55(42.0) \\
57(43.5) \\
40(30.0) \\
5(3.8)\end{array}$ & $\begin{array}{l}30(57.7) \\
20(38.5) \\
24(46.2) \\
15(28.8) \\
19(36.5) \\
3(5.8)\end{array}$ & $\begin{array}{l}46(58.2) \\
40(50.6) \\
31(39.2) \\
42(53.2) \\
21(26.6) \\
2(2.5)\end{array}$ & $\begin{array}{c}0.95 \\
0.17 \\
0.43 \\
0.006 \\
0.23 \\
0.34\end{array}$ \\
\hline $\begin{array}{l}\text { Affected side } \mathrm{n}(\%) \\
\text { - } \text { Right } \\
\text { - } \text { Left } \\
\text { - } \text { Bilateral } \\
\end{array}$ & $\begin{array}{c}61(46.6) \\
65(49.6) \\
5(3.8) \\
\end{array}$ & $\begin{array}{c}31(59.6) \\
20(38.5) \\
1(1.9) \\
\end{array}$ & $\begin{array}{c}31(39.2) \\
44(55.7) \\
4(5.1) \\
\end{array}$ & 0.1 \\
\hline $\begin{array}{l}\text { Level of consciousness n (\%) } \\
\text { - } \text { Alert } \\
\text { - } \text { Drowsy } \\
\text { - Stupor } \\
\text { - Coma } \\
\end{array}$ & $\begin{array}{l}52(39.7) \\
41(31.3) \\
28(21.4) \\
10(7.6)\end{array}$ & $\begin{array}{l}31(59.6) \\
10(19.2) \\
8(15.4) \\
3(5.8)\end{array}$ & $\begin{array}{l}21(26.6) \\
31(39.2) \\
20(25 \cdot 3) \\
7(8.9)\end{array}$ & 0.002 \\
\hline $\begin{array}{l}\text { Computed tomography n (\%) } \\
\text { - Normal } \\
\text { - Edema } \\
\text { - Infarction }\end{array}$ & $\begin{array}{l}65(49.6) \\
32(24.4) \\
34(26.0) \\
\end{array}$ & $\begin{array}{l}22(42.4) \\
15(28.8) \\
15(28.8) \\
\end{array}$ & $\begin{array}{l}43(54.4) \\
17(21.5) \\
19(24.1) \\
\end{array}$ & 0.39 \\
\hline $\begin{array}{l}\text { Carotid duplex } \mathrm{n}(\%) \\
\text { - } \\
\text { - } \\
\end{array}$ & $\begin{array}{l}43(32.8) \\
88(67.2)\end{array}$ & $\begin{array}{c}3(5.8) \\
49(94.2)\end{array}$ & $\begin{array}{l}40(50.6) \\
39(49.4)\end{array}$ & $<0.001$ \\
\hline $\begin{array}{cc}\text { Treatment } \mathrm{n}(\%) \\
- & \mathrm{LMWH} \\
- & \mathrm{rt}-\mathrm{PA} \\
\end{array}$ & $\begin{array}{l}80(61.1) \\
51(38.9) \\
\end{array}$ & $\begin{array}{l}31(59.6) \\
21(40.4)\end{array}$ & $\begin{array}{l}49(62.0) \\
30(38.0)\end{array}$ & 0.78 \\
\hline $\begin{array}{l}\text { Initiation of treatment } \mathrm{n}(\%) \\
-\quad \text { Early }(\leq 2 \mathrm{hr} .) \\
\text { - } \quad \text { Late }(>2 \mathrm{hr} .)\end{array}$ & $\begin{array}{c}90(68.7) \\
41(31.3)\end{array}$ & $\begin{array}{c}48(92.3) \\
4(7.7)\end{array}$ & $\begin{array}{l}42(53.2) \\
37(46.8)\end{array}$ & $<0.001$ \\
\hline $\begin{array}{l}\text { Angiography n (\%) } \\
\text { - Recanalization } \\
\text { - Occlusion }\end{array}$ & $\begin{array}{l}35(26.7) \\
96(73.3)\end{array}$ & $\begin{array}{l}26(50.0) \\
26(50.0)\end{array}$ & $\begin{array}{c}9(11.4) \\
70(88.6)\end{array}$ & $<0.001$ \\
\hline
\end{tabular}

Using logistic regression analysis, significant predictors of poor outcome on univariate analysis included age $\geq 60$ years
(OR:3.2, Cl: 1.3-7.9, $\mathrm{p}=0.014$ ), presence of atheromatous plaques (OR: $16.8, \mathrm{Cl}: 4.8$ 58.3, $\mathrm{p}<0.001)$, late initiation of treatment 
(OR: 10.6, $\mathrm{Cl}: 3.4-32.1, \mathrm{p}<0.001$ ) and persistent occlusion (OR: $7.8, \mathrm{Cl}$ : 3.2-18.8, $\mathrm{p}<$ 0.001). However, on multivariate analysis, variable predictive of poor outcome included age $\geq 60$ years (OR: $32.5, \mathrm{Cl}: 5.4-$
196.5, $p<0.001)$, presence of atheromatous plaques (OR: 9.4, $\mathrm{Cl}: 1.7-51.2, \mathrm{p}=0.01$ ), late initiation of treatment (OR: $10.0, \mathrm{Cl}$ : $1.5-67.1, \mathrm{p}=0.018)$ and persistent occlusion (OR:25.7, Cl: 6.9-95.8,p < 0.001) (Table 2).

\begin{tabular}{|c|c|c|c|c|c|c|}
\hline & \multicolumn{3}{|c|}{ Univariate analysis } & \multicolumn{3}{|c|}{ Multivariate analysis } \\
\hline & OR & $95 \% \mathrm{Cl}$ & $p$ & OR & $95 \% \mathrm{Cl}$ & $p$ \\
\hline $\begin{array}{c}\text { Age (years) n (\%) } \\
\qquad \quad<60 \\
\cdot \quad \geq 60\end{array}$ & $\begin{array}{c}\text { Ref. } \\
3.2\end{array}$ & $\begin{array}{c}- \\
1.3-7.9\end{array}$ & $\begin{array}{c}- \\
0.014\end{array}$ & $\begin{array}{c}- \\
32.5\end{array}$ & $\begin{array}{c}- \\
5.4-196.5\end{array}$ & $\begin{array}{c}- \\
<0.001\end{array}$ \\
\hline $\begin{array}{l}\text { Computed tomography n (\%) } \\
\text { - Normal } \\
\text { - Edema } \\
\text { - Infarction }\end{array}$ & $\begin{array}{c}\text { Ref. } \\
1.5 \\
0.9\end{array}$ & $\begin{array}{c}- \\
0.7-3.6 \\
0.3-2.4\end{array}$ & $\begin{array}{c}- \\
0.32 \\
0.82\end{array}$ & $\begin{array}{l}- \\
- \\
-\end{array}$ & $\begin{array}{l}- \\
- \\
-\end{array}$ & $\begin{array}{l}- \\
- \\
-\end{array}$ \\
\hline $\begin{array}{l}\text { Carotid duplex } \mathrm{n}(\%) \\
\text { - } \text { Free } \\
\text { - } \text { Atheromatous plaque }\end{array}$ & $\begin{array}{l}\text { Ref. } \\
16.8\end{array}$ & $\begin{array}{c}- \\
4.8-58.3\end{array}$ & $\begin{array}{c}- \\
<0.001\end{array}$ & $\begin{array}{c}- \\
9.4\end{array}$ & $\begin{array}{c}- \\
1.7-51.2\end{array}$ & $\begin{array}{c}- \\
0.01\end{array}$ \\
\hline $\begin{array}{c}\text { Treatment } \mathrm{n}(\%) \\
\text { - } \mathrm{rt-PA} \\
\text { - } \mathrm{LMWH}\end{array}$ & $\begin{array}{c}\text { Ref. } \\
1.1\end{array}$ & $\begin{array}{c}- \\
0.5-2.3\end{array}$ & $\begin{array}{c}- \\
0.78\end{array}$ & - & - & - \\
\hline $\begin{array}{l}\text { Initiation of treatment } \mathrm{n}(\%) \\
\text { - } \quad \text { Early }(\leq 2 \mathrm{hr} .) \\
\text { - } \quad \text { Late }(>2 \mathrm{hr} .)\end{array}$ & $\begin{array}{l}\text { Ref. } \\
10.6\end{array}$ & $\begin{array}{c}- \\
3.4-32.1\end{array}$ & $\begin{array}{c}- \\
<0.001\end{array}$ & $\begin{array}{c}- \\
10.0\end{array}$ & $\begin{array}{c}- \\
1.5-67.1\end{array}$ & $\begin{array}{c}- \\
0.018\end{array}$ \\
\hline $\begin{array}{l}\text { Angiography n (\%) } \\
\text { - Recanalization } \\
\text { - Occlusion }\end{array}$ & $\begin{array}{c}\text { Ref. } \\
7.8\end{array}$ & $\begin{array}{c}- \\
3.2-18.8\end{array}$ & $\begin{array}{c}- \\
<0.001\end{array}$ & $\begin{array}{c}- \\
25.7\end{array}$ & $\begin{array}{c}- \\
6.9-95.8\end{array}$ & $\begin{array}{c}- \\
<0.001\end{array}$ \\
\hline
\end{tabular}

\section{Discussion}

In this study, good functional outcome was achieved in 52 patients $(39.7 \%)$ of the studied AIS patients. We identified age $\geq 60$ years, presence of atheromatous plaques, early initiation of treatment and persistent occlusion after treatment as significant predictors of poor function outcome in 131 AIS patients after three months of initiation of treatment in univariate and multivariate analyses. These conclusions are generally in conformity with the study of Yeo et al(8). In their work on 2460 AIS patients, favorable functional outcome was reported in $49.4 \%$ of patients. Significant predictors of favorable function outcome comprised younger age, female gender, hypertension, NIHSS score at onset, recanalization on transcranial Doppler. However, in multivariate analysis, NIHSS score at onset and recanalization on transcranial Doppler remained as independent predictors of functional outcome. In the study of Kenmuir et al. ${ }^{(9)}$, however, good functional outcome was documented in $65.0 \%$ of patients. The authors reported age, NIHSS, ambulatory status, and ability to swallow as independent predictors of functional outcome. In another study, significant, male gender and NIHSS were the significant predictors of functional outcome at 3 months ${ }^{(10)}$. Similar conclusions were reported by the studies of Bhaskar et al. ${ }^{(11)}$ 
Wu et al. ${ }^{(12)}$ Thatikonda et al. ${ }^{(13)}$. Of note, the Egyptian study of Mohamed et al (14), older age, presence of diabetes and dyslipidemia was significant predictors of poor outcome reported in $50.0 \%$ of patients in that 157 patients study. In comparison, the study of Zhao et al(15) on 123 AIS patients, using multivariate analysis, good functional outcome was associated with short hospital stay and absence of poststroke cerebral edema or pneumonia. Interestingly, the study also identified having stroke in spring and summer seasons as significant predictor of good functional outcome. Also, in the study of Papamichalis et al(16) on 124 patients who received intravenous thrombolysis, good functional outcome was reported in $66.1 \%$ of patients. Factors associated with poor outcome at 3 months included hyperlipidemia, symptom-to-needle time, and vascular disease. Moreover, Naito et al(17) work noted a significant association between poor functional outcome and older age, lower body mass index, chronic heart failure, higher frequency of atrial fibrillation and anemia.

\section{Conclusion}

Functional outcome of AIS and its predictors reported by different studies is variable. This variation is probably attributed to demographic and logistic factors. In addition, the clinical characteristics of patients included in different studies can profoundly affect the outcome and its predictors.

Conflicts of Interest: No conflict of interest to declare.

Funding: None

\section{References}

1. Neuhaus A A, Couch Y, Hadley G, et al. Neuroprotection in stroke: the importance of collaboration and reproducibility. Brain 2017; 140 (8):2079-2092.

2. Moussaddy A, Demchuk A M, Hill M D. Thrombolytic therapies for ischemic stroke: Triumphs and future challenges. Neuropharmacology 2018; 134(Pt B):272-279.

3. Pierot L, Gawlitza M, Soize S. Techniques for endovascular treatment of acute ischemic stroke. Rev Neurol (Paris) 2017; 173(9):594-599.

4. Kim J S. tPA Helpers in the Treatment of Acute Ischemic Stroke: Are They Ready for Clinical Use? J Stroke 2019; 21(2):160-174.

5. Zhang Z, Pu Y, Mi D, et al. Cerebral Hemodynamic Evaluation After Cerebral Recanalization Therapy for Acute Ischemic Stroke. Front Neurol 2019; 10:719.

6. Bluhmki E, Chamorro A, Davalos A, et al. Stroke treatment with alteplase given 3.0-4.5 h after onset of acute ischaemic stroke (ECASS III): additional outcomes and subgroup analysis of a randomised controlled trial. Lancet Neurol 2009; 8(12):1095-1102.

7. de Haan R, Limburg $M$, Bossuyt $P$, et al. The clinical meaning of Rankin 'handicap' grades after stroke. Stroke 1995; 26(11):2027-2030.

8. Yeo L L, Paliwal P, Teoh H L, et al. Early and continuous neurologic improvements after intravenous thrombolysis are strong predictors of favorable long-term outcomes in acute ischemic stroke. J Stroke Cerebrovasc Dis 2013; 22(8):e590-596.

9. Kenmuir C L, Hammer M, Jovin T, et al. Predictors of Outcome in Patients Presenting with Acute Ischemic Stroke and Mild Stroke Scale Scores. J Stroke Cerebrovasc Dis 2015; 24(7):1685-1689.

10. Serrano-Ponz M, Rodrigo-Gasque C, Siles $\mathrm{E}$, et al. Temporal profiles of blood pressure, circulating nitric oxide, and adrenomedullin as predictors of clinical outcome in acute ischemic stroke patients. Mol Med Rep 2016; 13(5):3724-3734. 
11. Bhaskar S, Stanwell P, Bivard A, et al. The influence of initial stroke severity on mortality, overall functional outcome and in-hospital placement at 90 days following acute ischemic stroke: $\mathrm{A}$ tertiary hospital stroke register study. Neurol India 2017; 65(6):1252-1259.

12. Wu Z, Zeng $M$, Li $C$, et al. Timedependence of NIHSS in predicting functional outcome of patients with acute ischemic stroke treated with intravenous thrombolysis. Postgrad Med J 2019; 95(1122):181-186.

13. Thatikonda N, Khandait V, Shrikhande A, et al. Role of 24-Hr Blood Pressure Variability as a Target Therapeutic Risk Factor for Poor Functional Outcome of Acute Ischemic Stroke. Ann Indian Acad Neurol 2020; 23(1):25-31.

14. Mohamed A B, Elnady H M, Alhewaig H $\mathrm{K}$, et al. The mean platelet volume and plateletcrit as predictors of short-term outcome of acute ischemic stroke.
Egypt J Neurol Psychiatr Neurosurg 2019; 55(1):4.

15. Zhao Q, Shan W, Liu L, et al. Predictors of functional outcome and hemorrhagic complications in acute ischemic stroke patients treated with intravenous thrombolysis - A retrospective analysis. Int J Clin Pharmacol Ther 2017; 55(12):893-900.

16. Papamichalis $\mathrm{P}, \quad$ Karagiannis $\mathrm{S}$, Dardiotis E, et al. Predictors of Need for Critical Care Support, Adverse Events, and Outcome after Stroke Thrombolysis. J Stroke Cerebrovasc Dis 2018; 27(3):591-598.

17. Naito $H$, Nezu $T$, Hosomi $N$, et al. Controlling nutritional status score for predicting 3-mo functional outcome in acute ischemic stroke. Nutrition 2018; 55-56:1-6. 